\title{
Exploring the in Vitro Operating Window of Glycosyltransferase PtUGT1 from Polygonum tinctorium for a Biocatalytic Route to Indigo Dye
}

Petermeier, Philipp; Fortuna, Cristina; Hübschmann, Kathrine M.; Bidart, Gonzalo N.; Tørring, Thomas; Teze, David; Welner, Ditte H.; Kara, Selin

\section{Published in:}

ACS Sustainable Chemistry and Engineering

Link to article, DOI:

10.1021/acssuschemeng.1c01536

Publication date:

2021

Document Version

Publisher's PDF, also known as Version of record

Link back to DTU Orbit

Citation $(A P A)$ :

Petermeier, P., Fortuna, C., Hübschmann, K. M., Bidart, G. N., Tørring, T., Teze, D., Welner, D. H., \& Kara, S. (2021). Exploring the in Vitro Operating Window of Glycosyltransferase PtUGT1 from Polygonum tinctorium for a Biocatalytic Route to Indigo Dye. ACS Sustainable Chemistry and Engineering, 9(25), 8497-8506.

https://doi.org/10.1021/acssuschemeng.1c01536

\section{General rights}

Copyright and moral rights for the publications made accessible in the public portal are retained by the authors and/or other copyright owners and it is a condition of accessing publications that users recognise and abide by the legal requirements associated with these rights.

- Users may download and print one copy of any publication from the public portal for the purpose of private study or research.

- You may not further distribute the material or use it for any profit-making activity or commercial gain

- You may freely distribute the URL identifying the publication in the public portal 


\title{
Exploring the in Vitro Operating Window of Glycosyltransferase PtUGT1 from Polygonum tinctorium for a Biocatalytic Route to Indigo Dye
}

\author{
Philipp Petermeier, Cristina Fortuna, Kathrine M. Hübschmann, Gonzalo N. Bidart, Thomas Tørring, \\ David Teze, Ditte H. Welner, and Selin Kara*
}

Cite This: ACS Sustainable Chem. Eng. 2021, 9, 8497-8506

Read Online

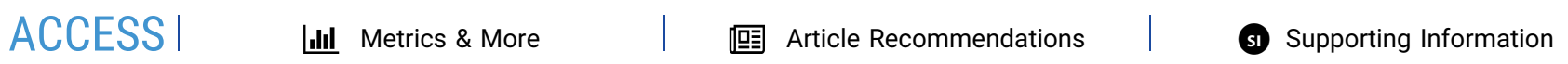

ABSTRACT: The eobiotic compound indican lends itself to a compelling biocatalytic dyeing strategy for denim, in which the formation of corrosive byproducts is avoided. However, the efficient and scalable production of indican remains a key bottleneck. This work focuses on the in vitro characterization of PtUGT1, a glycosyltransferase from Polygonum tinctorium that catalyzes the formation of indican via the glycosylation of indoxyl. Here, the buffer composition and enzyme concentration were identified as key parameters for enzyme activity and stability. The short lifetime of the enzyme under reaction conditions initiated an immobilization study. As a consequence, an amino-functionalized methacrylate resin was identified as a highly functional option for efficient immobilization of PtUGT1, allowing immobilization

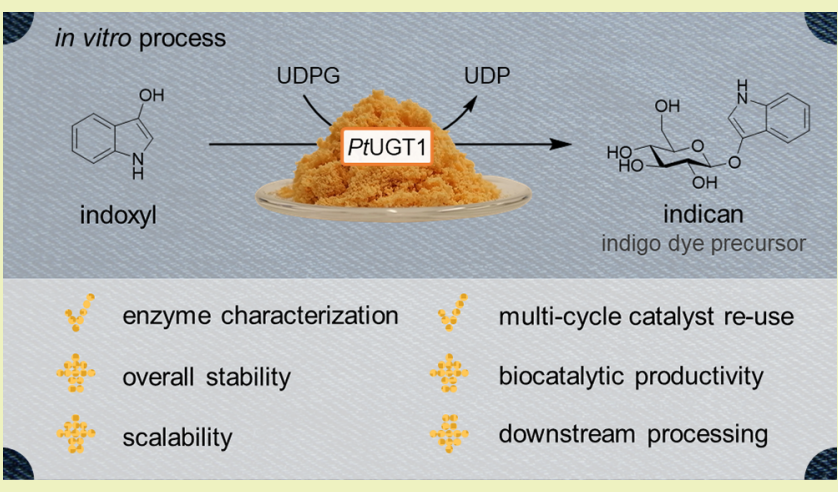
yields of $>98 \%$ for enzyme loadings up to $7.6 \mathrm{wt} \%$. We further report a stabilization factor of 47 and significantly improved overall biocatalytic productivity. The straightforward handling and reuse of the described heterogeneous biocatalyst is demonstrated. KEYWORDS: Glycosylation, Enzyme immobilization, Bioprocess engineering, Denim dyes, Green manufacturing, Glycosyltransferase

\section{INTRODUCTION}

Indigo dye is believed to be the oldest dye known to mankind. ${ }^{1}$ It allows for a robust deep blue coloring, which originally was achieved by crushing and applying dye-producing plants to a given substrate. In all likelihood, this was already recognized by the earliest man in regions of indigo-bearing plants. ${ }^{2}$ It is thus not surprising that historical and analytical reports attest the later, longstanding, purposeful trade and use of natural indigo by the ancient Egyptians, Greeks, and Romans. ${ }^{3-5}$ Findings of its widespread use in many early cultures all over the world emphasize that indigo has always been one of the most important and popular dyes. ${ }^{6-8}$ The success story of the colorful molecule continued relentlessly through the ages and experienced an impressive boom after blue jeans were introduced in the U.S. ${ }^{9}$ Initially, denim products were intended for hard-wearing work clothes, but they quickly caught on and established themselves as a fashionable item of clothing. ${ }^{10}$ The consequently increasing demand for the dye in combination with a revolution in the chemical industry triggered the search for synthetic routes enabling indigo production. Adolf von Baeyer, the first to identify the chemical structure of indigo and to patent a synthesis, was awarded a Nobel Prize in 1905 for his research on "organic dyestuffs and hydroaromatic compounds.” When BASF SE (Germany) launched their first industrial-scale process based on coal tar in 1897, it was not long before other firms followed suit and synthetic indigo replaced the natural compound. ${ }^{2}$ Although alternative blue dyes are available nowadays, the appeal of indigo is unabated, and it remains the first choice as a denim dye. Arguably this can be ascribed to its unique dyeing properties, since it does not covalently bind but instead strongly adsorbs when precipitated on cotton fibers. As such, indigo is resilient to strong detergents but susceptible to mechanical abrasion or biochemical treatment. ${ }^{11}$ This allows processing of dyed garments to attain their characteristic soft to faded look. The unbroken popularity of denim is well reflected in the considerable annual production of 50000 tons of indigo (status 2011). ${ }^{9}$ Also, it is strongly tied to a global market for denim that surmounted 90 billion U.S. dollars in $2019 .{ }^{12}$ However, as already pointed out in earlier work, ${ }^{13}$ the production of indigo is associated with two major sustainability

Received: March 5, 2021

Revised: $\quad$ May 8, 2021

Published: June 11, 2021 
problems: First, conventional chemical synthesis relies on fossil fuel based, hazardous raw materials such as aniline, formaldehyde, and hydrogen cyanide to produce indoxyl, the precursor to indigo. Second, since indigo is insoluble in water it requires reduction to its water-soluble leuco-indigo form to be used as dyestuff..$^{2}$ The most common strategy is to use an excess of sodium dithionite as a strong reducing agent. ${ }^{10}$ Yet, this generates large amounts of wastewater loaded with corrosive sulfite and sulfate salts. ${ }^{9}$ To tackle the first problem, alternative biocompatible routes using renewable resources and engineered microbes were proposed: Genencor International B.V. (The Netherlands) reported a fermentation process with recombinant Escherichia coli to produce indigo from glucose. ${ }^{14}$ Fabara et al. used E. coli cells containing a bifunctional fusion enzyme, consisting of a flavin-containing monooxygenase (FMO) and a tryptophanase (TRP), which consumed Ltryptophan and yielded $1.7 \mathrm{~g} / \mathrm{L}$ indigo. ${ }^{15}$ For a comprehensive overview of enzymes that can be utilized to produce indigo, we refer to a recent review from Fraaije and Fabara. ${ }^{16}$ Notably, the in vivo production of indigo in cell factories is often limited by the complexity of the system as well as by cumbersome downstream processing. Furthermore, the problematic chemical reduction of indigo as required for dyeing is still the same as in the conventional process. In 2018, Hsu et al. described a bioinspired dyeing strategy that eliminates the need for reducing agents by telescoping the biocatalytic cascade in $E$. coli from L-tryptophan to indican. It is a protected and stabilized form of indoxyl, which can be stored, shipped, and converted back to indoxyl with a $\beta$-glucosidase (BGL). ${ }^{13,17}$ The here presented work focuses on process engineering of the critical step that is a prerequisite for biocatalytic indigo dyeing, i.e., the glycosylation by uridine diphosphate (UDP)glycosyltransferase from Polygonum tinctorium, PtUGT1. ${ }^{13}$ We characterize free and immobilized enzyme preparations with respect to their overall productivity and discuss their potential for in vitro glycosylation to be coupled with upstream indoxyl production.

\section{EXPERIMENTAL SECTION}

Materials. 3,4-Dichlorophenol (DCP, 99\% grade) was purchased from Alfa Aesar (U.S.). UDP- $\alpha$-D-glucose disodium salt (UDPG, $\geq$ $98 \%$ grade) was obtained from Cayman Chemical (U.S.). Sodium chloride (p.a., ACS, ISO), sodium hydroxide ( $\geq 98 \%$ ), and formic acid (98-100\%) were purchased from Merck KGaA (Germany). Trifluoroacetic acid (TFA, biotechnology grade) and HEPES (biochemistry grade) were bought from VWR International (Germany). The Pierce $660 \mathrm{~nm}$ protein assay reagent was obtained from Thermo Fisher Scientific (Germany) and Albumin bovine Fraction V (BSA, standard grade, lyophilized) for calibration of the protein assay was from SERVA Electrophoresis GmbH (Germany). Lifetech carrier materials for enzyme immobilization were generously provided by Purolite Ltd. (U.K.): ECR8204F, ECR8209F, ECR8215F, ECR8304F, ECR8315F, ECR8404F, ECR8409F, and ECR8415F. Glutaraldehyde (50\% solution in water) used for preactivation of amino Lifetech carriers was obtained from SigmaAldrich (Germany). Acetonitrile ( $\geq 99.95 \%$, UHPLC grade) used for HPLC was purchased from VWR International (Germany).

Expression and Purification of PtUGT1. Ten milliliter precultures of Rosetta (DE3) cells (Novagen, Merck KGaA Germany) carrying $\mathrm{pTMH} 307^{13}$ in $2 \mathrm{xYT}$ media containing ampicillin $(100 \mu \mathrm{g} / \mathrm{mL})$ were grown overnight and used to inoculate $1 \mathrm{~L}$ cultures of 2xYT media with ampicillin selection. Cultures were grown at $37{ }^{\circ} \mathrm{C}$ in a MaxQ8000 incubator (Thermo Fisher Scientific, Germany) at $200 \mathrm{rpm}$ and induced with $0.2 \mathrm{mM}$ isopropyl- $\beta$-Dthiogalactopyranoside (IPTG) at $\mathrm{OD}_{600} \sim 1$. Cultures were then grown at $18{ }^{\circ} \mathrm{C}$ for $21 \mathrm{~h}$ for protein expression, and the cells were harvested by centrifugation. The cell pellets were resuspended in $50 \mathrm{mM}$ HEPES at $\mathrm{pH} 7.0,300 \mathrm{mM} \mathrm{NaCl}$, and $40 \mathrm{mM}$ imidazole at $\mathrm{pH}$ 8.0. The cell suspension was lysed with two cycles through an Avestin Emulsiflex C5 (ATA Scientific Pty Ltd., Australia) homogenizer and treated with DNase. Cell debris was removed by centrifugation at $15000 \mathrm{~g}$ for $20 \mathrm{~min}$ at $4{ }^{\circ} \mathrm{C}$. The cleared extracts were loaded onto Ni Sepharose Fast Flow columns (HisTrap affinity columns, GE Healthcare, U.S.), and the protein was purified using an Äkta FPLC system (GE Healthcare, U.S.). After washing the columns with buffer (50 mM HEPES at $\mathrm{pH} 7.0,300 \mathrm{mM} \mathrm{NaCl}$, and $40 \mathrm{mM}$ imidazole $\mathrm{pH} 8.0$ ), elution was carried out with a $40-500 \mathrm{mM}$ imidazole gradient. The peak fractions were analyzed by SDS-PAGE using NuPAGE 4-12\% Bis-Tris Protein Gels (Thermo Fisher Scientific, U.S.) stained with Instant Blue (Expedeon Ltd. U.K.) pooled, concentrated using a 50000 MWCO Amicon Ultra-15 Centrifugal Filter Unit (Merck Millipore, Germany) and stored in $25 \mathrm{mM}$ HEPES at $\mathrm{pH} 7,50 \mathrm{mM} \mathrm{NaCl}$, and $1 \mathrm{mM}$ DTT.

Protein Assay. All enzyme concentrations used in this work are based on the results from the Pierce bicinchoninic acid (BCA) protein assay. Calibration was done with bovine serum albumin (BSA) standards in the range $50-2000 \mathrm{mg} / \mathrm{L}$. Standards were prepared in the same buffer as the samples. For each measurement, $10 \mu \mathrm{L}$ of standard or sample was transferred to the $96-$ well plate, and $150 \mu \mathrm{L}$ of Pierce protein assay reagent was added. After incubation for $5 \mathrm{~min}$ at room temperature, the absorbance was measured at $660 \mathrm{~nm}$ and $25 \pm$ $0.5{ }^{\circ} \mathrm{C}$ (25 flashes per read) using the NanoQuant infinite M2000 PRO plate reader (TECAN Austria, Austria). Both standards and samples were measured in triplicate.

Handling of the Biocatalyst. PtUGT1 stocks as prepared above were shock-frozen in liquid nitrogen and stored at $-20{ }^{\circ} \mathrm{C}$. Only directly prior to use were aliquots thawed at $+4{ }^{\circ} \mathrm{C}$. Cooled and careful handling of the enzyme solution was ensured at all stages, especially since it is observed that the enzyme preparation is sensitive to foaming. For efficient mixing of reaction solutions containing enzymes, damped vortexing was employed to avoid foam formation and thus enzyme deactivation at the gas-liquid interphase.

Kinetic Assay for Free Enzyme. Glycosyltransferase activity was measured using 3,4-dichlorophenol (DCP) as model substrate in aqueous media. Generally, reactions were conducted at $2.5 \mathrm{mM}$ UDP$\alpha$-D-glucopyranoside (UDPG), $0.50 \mathrm{mM} \mathrm{DCP}$, and $9-13 \mathrm{mg} / \mathrm{L}$ PtUGT1. For this, $100 \mu \mathrm{L}$ of a $25 \mathrm{mM}$ UDPG stock was mixed with $250 \mu \mathrm{L}$ of a $2.0 \mathrm{mM}$ DCP stock and the respective amount of buffer/ water to give a total reaction volume of $1.0 \mathrm{~mL}$ after the addition of enzyme stock. All UDPG stocks were freshly prepared before each experiment by dissolving the required amount of UDPG disodium salt in the respective aqueous medium. The aqueous $2.0 \mathrm{mM}$ DCP stock was stored in the fridge to be used in experiments on several consecutive days. Prior to the addition of the enzyme to the substrate solution-marking the reaction start-both the separate aqueous enzyme and substrate solutions were incubated at $40{ }^{\circ} \mathrm{C}$ and $1000 \mathrm{rpm}$ on the MKR 23 Thermoshaker (Hettich Benelux, The Netherlands) for $5 \mathrm{~min}$. Samples $(100 \mu \mathrm{L})$ were withdrawn within 8 min, quenched with $5 \mu \mathrm{L}$ of trifluoroacetic acid (TFA) and diluted with $295 \mu \mathrm{L}$ of HEPES buffer ( $\mathrm{pH} 7.0,25 \mathrm{mM}$ HEPES, $50 \mathrm{mM}$ $\mathrm{NaCl}$ ). The exact quenching times after the reaction start were reported. All aliquots (quenched samples) were vortexed immediately, centrifuged (13400 rpm, $2 \mathrm{~min})$, transferred to glass vials, and subjected to HPLC analysis as described below.

Enzyme Immobilization Procedure for Epoxy Carriers. Prior to enzyme immobilization, the carrier beads were washed with roughly $1.0 \mathrm{~mL}$ of HEPES buffer ( $\mathrm{pH} 7.0,25 \mathrm{mM}$ HEPES, $50 \mathrm{mM}$ $\mathrm{NaCl}$ ) per $200 \mathrm{mg}$ of wet carrier. For this, the beads were mixed with the buffer in a microcentrifuge tube and gently mixed on an LLGuniRotator2 end-over-end mixer (Lab Logistic Group, Meckenheim, Germany) for $2 \mathrm{~min}$. The mixture was centrifuged (13 $400 \mathrm{rpm}$, $2 \mathrm{~min}$ ), and the supernatant was discarded. The washing step was repeated two more times. After the third washing step, the beads were separated from the supernatant by vacuum filtration. For immobilization, $30-100 \mathrm{mg}$ of carrier beads were weighed in a $2.0 \mathrm{~mL}$ 
microcentrifuge tube, and the corresponding amount of enzyme stock $(5-7 \mathrm{mg} / \mathrm{mL}$ in HEPES buffer) required for a desired total enzymecarrier ratio $[\mathrm{mg} / \mathrm{g}]$ was added. Up to $200 \mu \mathrm{L}$ of HEPES buffer $(\mathrm{pH}$ 7.0, $25 \mathrm{mM}$ HEPES, $50 \mathrm{NaCl}$ ) was added in case the beads were not fully submerged. The slurry was gently mixed at room temperature for $5 \mathrm{~h}$ at the lowest setting of the end-over-end mixer. Then, the immobilization mixture was stored at $+4{ }^{\circ} \mathrm{C}$ for $16 \mathrm{~h}$. After immobilization, the mixture was vacuum filtered, the liquid fraction collected, and its volume noted. The beads were washed two more times with $<2 \mathrm{~mL}$ of HEPES buffer each. The supernatants from these washing steps were collected as well. The protein concentrations in all three supernatants per immobilization were analyzed with the Pierce BCA protein assay and used to calculate enzyme loading and immobilization yield. The immobilized biocatalyst preparations were stored in microcentrifuge tubes at $+4{ }^{\circ} \mathrm{C}$.

Enzyme Immobilization Procedure for Amino Carriers. Prior to enzyme immobilization, the carrier beads were washed with roughly $1.0 \mathrm{~mL}$ of HEPES buffer ( $\mathrm{pH} 7.0,25 \mathrm{mM}$ HEPES, $50 \mathrm{mM}$ $\mathrm{NaCl}$ ) per $100 \mathrm{mg}$ of carrier. For this, the beads were mixed with the buffer in a microcentrifuge tube and gently mixed on a LLGuniRotator2 end-over-end mixer (Lab Logistic Group, Germany) for $2 \mathrm{~min}$. The supernatant was removed by vacuum filtration. Next, the beads were incubated with $250 \mu \mathrm{L}$ of glutaraldehyde solution ( $2 \%$ (v/ $\mathrm{v}$ ) in water) for $1 \mathrm{~h}$ on the end-over-end mixer at room temperature. Next, the aldehyde solution was removed by vacuum filtration; the beads were washed twice with HEPES buffer and used for immobilization on the same day. For this, $30-100 \mathrm{mg}$ of carrier beads were weighed in a $2.0 \mathrm{~mL}$ microcentrifuge tube, and the corresponding amount of enzyme stock $(5-7 \mathrm{mg} / \mathrm{mL}$ in HEPES buffer) required for a desired total enzyme-carrier ratio $\left[\mathrm{mg}_{\text {enzyme }} /\right.$ $\mathrm{g}_{\text {carrier }}$ ] was added. Up to $200 \mu \mathrm{L}$ of HEPES buffer ( $\mathrm{pH} 7.0,25 \mathrm{mM}$ HEPES, $50 \mathrm{mM} \mathrm{NaCl}$ ) was added in case the beads were not fully submerged. The slurry was gently mixed at room temperature for $18.5 \mathrm{~h}$ at the lowest speed setting of the end-over-end mixer. After immobilization, the mixture was vacuum filtered, the liquid fraction collected, and its volume noted. The beads were washed two more times with $<2 \mathrm{~mL}$ of HEPES buffer each. The supernatants from these washing steps were collected as well. The protein concentration in all three supernatants per immobilization were analyzed with the Pierce $\mathrm{BCA}$ protein assay and used to calculate enzyme loading and immobilization yield. The immobilized biocatalyst preparations were stored in microcentrifuge tubes at $+4{ }^{\circ} \mathrm{C}$.

Enzyme Loading and Immobilization Yield. The enzyme loading $\left[\mathrm{mg}_{\text {enzyme }} / \mathrm{g}_{\text {carrier }}\right]$ was calculated based on the enzyme amount offered, the sum of all residual enzymes in any of the supernatants collected after immobilization, as well as the amount of wet carrier used.

$$
\begin{aligned}
\text { enzyme loading }[\mathrm{mg} / \mathrm{g}] & =\frac{m(\mathrm{E})_{\text {offered }}-m(\mathrm{E})_{\text {remaining }}}{m_{\text {carrier }}} \\
& =\frac{\left[\mathrm{mg}_{\text {enzyme }}\right]}{\left[\mathrm{g}_{\text {carrier }}\right]}
\end{aligned}
$$

Similarly, the immobilization yield was derived from the offered amount of enzyme and remaining enzyme amounts in the immobilization and washing supernatants.

$$
\eta_{\text {immo }}[\%]=\frac{m(\mathrm{E})_{\text {offered }}-m(\mathrm{E})_{\text {remaining }}}{m(\mathrm{E})_{\text {offered }}}=\frac{\left[\mathrm{mg}_{\text {enzyme }}\right]}{\left[\mathrm{mg}_{\text {enzyme }}\right]} \times 100 \%
$$

Progress Curve Analyses for Immobilized Enzymes. To track enzymatic activity and performance of immobilized enzyme preparation, progress curves (i.e., monitoring of substrate depletion and product formation) were recorded. All reactions were performed in $2.0 \mathrm{~mL}$ microcentrifuge tubes, at standard concentrations of $2.5 \mathrm{mM}$ UDPG and $0.50 \mathrm{mM}$ DCP in a total reaction volume of $1.5 \mathrm{~mL}$ of aqueous media. The immobilized enzyme preparations used at this scale were in the range of $1-6 \mathrm{mg}$ per reaction. For this, the enzyme beads were mixed with $150 \mu \mathrm{L}$ of a freshly prepared $25 \mathrm{mM}$ UDPG stock, $975 \mu \mathrm{L}$ of buffer (pH 7.0, $25 \mathrm{mM}$ HEPES, $50 \mathrm{mM}$ $\mathrm{NaCl}$ ), and last $375 \mu \mathrm{L}$ of $2.0 \mathrm{mM}$ DCP stock to give a total reaction volume of $1.5 \mathrm{~mL}$. Prior to the addition of DCP stock-marking the reaction start-the prepared reaction mixture consisting of buffer, UDPG stock, and enzyme beads as well as the separate substrate stock were incubated for $5 \mathrm{~min}$ at $40{ }^{\circ} \mathrm{C}$ and $1000 \mathrm{rpm}$ on the MKR 23 Thermoshaker (Hettich Benelux, The Netherlands). After the reaction start, samples of the supernatant were withdrawn over a period of $90 \mathrm{~min}$, quenched with $5 \%(\mathrm{v} / \mathrm{v})$ TFA, and diluted with buffer ( $\mathrm{pH}$ 7.0, $25 \mathrm{mM}$ HEPES, $50 \mathrm{mM} \mathrm{NaCl}$ ). The quenching step was kept precluding effects by unexpected enzyme leaching. The exact sampling times after reaction start were reported. All aliquots (quenched samples) were vortexed immediately, centrifuged (13 $400 \mathrm{rpm}, 2 \mathrm{~min}$ ), transferred to glass vials, and subjected to HPLC analysis as described below.

Specific Activities and Activity Yields of Immobilized Enzymes. Kinetic characterizations of heterogeneous enzyme preparations were solely based on progressive curves of DCPG formation. Due to the ubiquitous availability of DCP at reaction start and its pronounced tendency to be taken up by the carrier, initial rates derived from apparent DCP consumption would give severe overestimations. By deriving initial rates from DCPG formation, the absolute error is reduced (lower retention tendency) and the derived activities are rather slightly underestimated than overestimated. For flat DCPG progress courses, initial rates $r_{i}$ were obtained by linear regression of data points at $<10 \%$ conversion. Progress curves with particularly steep initial reaction progress and subsequent slowdown (as in Figure 6) were fitted with a hyperbolic function using the Levenberg-Marquardt algorithm. From the respective fit, initial rates $r_{i}$ were derived for more productive preparations. The specific activity $a$ was calculated therefrom using the given relation:

$$
\begin{array}{r}
a \text { specific activity }\left[\mathrm{U} / \mathrm{g}_{\text {preparation }}\right]=\frac{r_{i} \cdot V_{\text {reaction }}}{m_{\text {preparation }}} \\
=\frac{[\mu \mathrm{mol} / \mathrm{L} / \mathrm{min}] \cdot[\mathrm{L}]}{\left[\mathrm{g}_{\text {preparation }}\right]}
\end{array}
$$

From this, the residual enzyme specific activity was estimated by using the enzyme loading.

$$
\begin{gathered}
a_{\mathrm{E}} \text {, enzyme }- \text { specific activity }\left[\mathrm{U} / \mathrm{g}_{\text {enzyme }}\right]=\frac{\text { specific activity }}{\text { enzyme loading }} \\
=\frac{\left[\mathrm{U} / \mathrm{g}_{\text {preparation }}\right]}{\left[\mathrm{g}_{\text {enzyme }} / \mathrm{g}_{\text {carrier }}\right]}
\end{gathered}
$$

The activity yield was calculated as given below and is based on the amount of enzyme offered for immobilization, the specific activity of free enzyme according to the reported standard kinetic assay, the amount of carrier used for a respective immobilization, and the initial rates observed for the given immobilized enzyme preparation.

$$
\eta_{\text {activity }}[\%]=\frac{a_{\text {immo }} \cdot m_{\text {carrier }}}{a_{\text {free }} \cdot m(\mathrm{E})_{\text {offered }}}=\frac{\left[\mathrm{U} / \mathrm{g}_{\text {preparation }}\right] \cdot\left[\mathrm{g}_{\text {preparation }}\right]}{\left[\mathrm{U} / \mathrm{mg}_{\text {enzyme }}\right] \cdot\left[\mathrm{mg}_{\text {enzyme }}\right]} \cdot 100 \%
$$

High-Performance Liquid Chromatography (HPLC). All HPLC analyses were performed on an Agilent Technologies 1260 Series Infinity II system (Germany) consisting of a G7111B quaternary pump, a G7129A vial sampler, a G7116A column thermostat, and a G7117C diode-array detector (DAD) interfaced with a G6125C LC-ESI-MS detector. For separation of the analytes, the Kinetex $5 \mu \mathrm{M}$ C18 $100 \AA \mathrm{LC}$ column $(250 \times 4.6 \mathrm{~mm}$, Phenomenex) was used together with a gradient of (A) Milli- $\mathrm{Q}$ water with $0.1 \%(\mathrm{v} / \mathrm{v})$ formic acid and (B) acetonitrile with $0.1 \%(\mathrm{v} / \mathrm{v})$ formic acid as given: $0-2 \mathrm{~min}(95 \mathrm{~A} / 5 \mathrm{~B}, \mathrm{v} / \mathrm{v}), 2-3.5 \mathrm{~min}(80 \mathrm{~A} / 20 \mathrm{~B})$, 3.5-7 $\mathrm{min}$ (ramp to $0 \mathrm{~A} / 100 \mathrm{~B}), 7-12 \mathrm{~min}(0 \mathrm{~A} / 100 \mathrm{~B}), 12-13 \mathrm{~min}$ (ramp to $95 \mathrm{~A} / 5 \mathrm{~B}), 13-14 \mathrm{~min}(95 \mathrm{~A} / 5 \mathrm{~B})$. The sample injection volume was $10 \mu \mathrm{L}$; the column oven temperature, $35 \pm 0.5{ }^{\circ} \mathrm{C}$; and 
the total flow rate, $0.7 \mathrm{~mL} / \mathrm{min}$. The $\mathrm{DAD}$ was set to simultaneously record wavelengths $210,240,260,280$, and $290 \mathrm{~nm}$ to check for byproducts. No reference wavelengths were used. The $290 \mathrm{~nm}$ channel was used for calibration and quantification. For calibration, a $2.0 \mathrm{mM}$ DCP stock in HEPES buffer ( $\mathrm{pH} 7.0,25 \mathrm{mM}$ HEPES, $50 \mathrm{mM} \mathrm{NaCl}$ ) was diluted to standards in the range $5-500 \mu \mathrm{M}$ using the same buffer. All calibration standards were prepared in triplicate. Since DCPG is not commercially available and therefore could not be used as a standard, the DCPG calibration was done indirectly assuming a closed mass balance in homogeneous reaction mixtures without a carrier. For these reactions, the amount of DCP converted was equated with the amount of DCPG formed, and this in turn was correlated with the detected DCPG peak area. For measurements, the samples of the different assays were directly injected as prepared in the respective procedures. The obtained standard curve and an exemplary chromatogram showing the separation of DCP and DCPG are provided in the Supporting Information, Figures S1-S3.

\section{RESULTS AND DISCUSSION}

The enzyme PtUGT1 effectively glycosylates indoxyl, forming the stable, natural compound indican. For this reaction, Hsu et al. ${ }^{13}$ reported kinetic experiments at an enzyme concentration of $20 \mathrm{nM}$ - roughly $1 \mathrm{mg} / \mathrm{L}$ - in an aqueous reaction buffer of pH 7.8 consisting of $50 \mathrm{mM}$ HEPES, $50 \mathrm{mM} \mathrm{NaCl}, 10 \mathrm{mM}$ dithiothreitol (DTT), and $5 \mathrm{mM}$ UDP- $\alpha$-D-glucopyranoside (UDPG). Although the kinetic studies reported in Hsu et al. were performed in an anaerobic environment, the $K_{\mathrm{M}}$ value could not be elucidated accurately due to the instability of the substrate. ${ }^{13}$ In the present work, an efficient immobilized preparation of PtUGT1 was pursued to facilitate the technical in vitro synthesis of indican. For this purpose, however, the analytics for characterization of the free and immobilized biocatalysts were not based on the eventual substrate indoxyl but on the well-accepted model compound 3,4-dichlorophenol (DCP; see Figure 1). ${ }^{18}$ This measure was taken (i) to improve

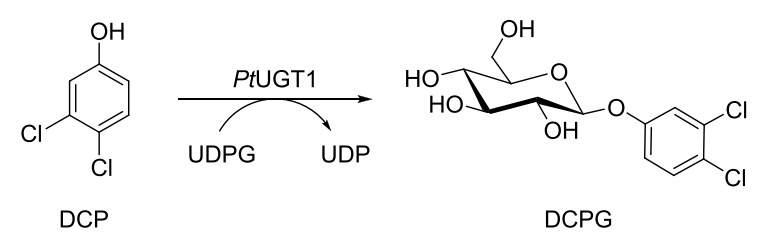

Figure 1. Enzymatic glycosylation of model substrate 3,4-dichlorophenol (DCP) catalyzed by PtUGT1 using UDP- $\alpha$-D-glucopyranoside (UDPG) yields 3,4-dichlorophenol glucoside (DCPG).

intrinsic analytical precision by removing errors caused by analyte instabilities, (ii) to use a commercially available substrate of high purity, eliminating needs for upstream in situ indoxyl generation, and therefore (iii) facilitating a more economic and ecologic screening process by avoiding otherwise necessary material and time-consuming steps. DCP was selected as a model compound since it is a readily available substrate of comparable molecular weight, water solubility, $\mathrm{p} K_{a}$, and hydrophobicity $(\log \mathrm{P})$ as given in Table 1.

Due to a lack of experimental data for indoxyl in the literature, the values given are predicted values, calculated in the ACD/Laboratories Software by Advanced Chemistry Development, Inc. ${ }^{22}$

$\mathrm{pH} 7.0$ has previously been identified as the optimum $\mathrm{pH}$ for the glycosylation of DCP by PtUGT $1 .{ }^{18}$ Thus, for further characterization of the free enzyme, we as well opted for the HEPES buffer at this $\mathrm{pH}$. However, considering the potential technical relevance of biocatalytic indican and the associated
Table 1. Comparison of Physicochemical Properties of the Target Substrate Indoxyl and the Model Compound DCP Used in This Work

\begin{tabular}{lccr}
\multicolumn{1}{c}{ parameter } & indoxyl & $\mathrm{DCP}^{19-21}$ & \multicolumn{1}{c}{ [units $]$} \\
molecular weight & 133 & 163 & {$[\mathrm{~g} / \mathrm{mol}]$} \\
water solubility $\left(25^{\circ} \mathrm{C}\right)$ & 33 & 57 & {$[\mathrm{mmol} / \mathrm{L}]$} \\
$\mathrm{pK}{ }_{\mathrm{a}}\left(25^{\circ} \mathrm{C}\right)$ & 10.1 & 8.59 & {$[-]$} \\
$\log P$ & 1.95 & 3.4 & {$[-]$} \\
\hline
\end{tabular}

economic requirements, there is limited utility in the evaluation of conditions which are too far from economic feasibility. Thus, in contrast to the earlier mentioned work by Hsu et al., ${ }^{13}$ we excluded the use of costly DTT in the reaction buffer and halved the concentration of HEPES to $25 \mathrm{mM}$. On the lab scale, this measure reduced the costs per liter of reaction buffer by $88 \%$. The accordingly reduced buffer capacity was considered unproblematic, since it is still well above substrate concentrations used for kinetic investigations.

For kinetic experiments, we used UDPG concentrations 5fold higher than the respective DCP concentrations. This was done to ensure cosubstrate ubiquity and to render reaction kinetics decoupled from UDPG concentration. Initial kinetic experiments for DCP concentrations of $200-500 \mu \mathrm{M}$ revealed no dependency of the reaction rate on substrate concentrations within this range. Assuming Michaelis-Menten kinetics, we concluded that these concentrations are well above the $K_{M}$ for DCP. The specific activity and catalytic constant derived for $500 \mu \mathrm{M}$ DCP are given in Table 2 , entry 1 . Since a neutral pH

Table 2. Characteristic Kinetic Constants of PtUGT1 in HEPES buffer, Milli-Q Water, and a Saline Solution of Same Ionic Strength As the Buffered System ${ }^{a}$

\begin{tabular}{|c|c|c|c|}
\hline entry & reaction media & $\begin{array}{c}\text { specific activity - } \\
v_{\max } /[\mathrm{E}]\end{array}$ & $\begin{array}{l}\text { reaction rate } \\
\text { constant }-k_{\text {cat }}\end{array}$ \\
\hline 1 & $\begin{array}{l}\text { HEPES buffer, pH } 7.0 \\
(25 \mathrm{mM} \mathrm{HEPES}, 50 \\
\mathrm{mM} \mathrm{NaCl})\end{array}$ & $2.49 \pm 0.14 \mathrm{U} / \mathrm{mg}$ & $135.6 \pm 7.9 \mathrm{~min}^{-1}$ \\
\hline 2 & $\begin{array}{l}\text { saline solution, } \mathrm{pH} 7.0 \\
\quad(56 \mathrm{mM} \mathrm{NaCl})\end{array}$ & $1.11 \pm 0.10 \mathrm{U} / \mathrm{mg}$ & $60.3 \pm 5.5 \mathrm{~min}^{-1}$ \\
\hline 3 & Milli-Q water & $0.88 \pm 0.04 \mathrm{U} / \mathrm{mg}$ & $48.1 \pm 2.4 \mathrm{~min}^{-1}$ \\
\hline
\end{tabular}

${ }^{a}$ Standard deviations are based on sextuplicates for entry 1 and on triplicates for entries 2 and 3. Reaction conditions: $500 \mu \mathrm{M}$ DCP, 2.5 $\mathrm{mM}$ UDPG, $10 \mathrm{mg} / \mathrm{L}$ enzyme, at $40{ }^{\circ} \mathrm{C}$ and $1000 \mathrm{rpm}$.

was found optimal for the enzyme, we tested if the enzyme preserves its catalytic activity when used in water only. For this, the comparatively complex buffer system was substituted with Milli-Q water and the kinetic assay repeated under otherwise identical conditions. Although glycosylation of DCP was observed, the specific activity of PtUGT1 was strongly reduced under these conditions (see Table 2, entry 3 ). With the $\mathrm{pH}$ virtually the same as under buffered conditions, we set out to test whether the change in ionic strength can be correlated with the loss in enzymatic activity. Interactions of ions or charged organic species with polar surface functionalities and $\alpha$-helix dipoles of PtUGT1 may influence stability and mobility and thus enzyme activity. To test this, we ran kinetic assays with the reaction media switched to an aqueous solution of $\mathrm{NaCl}$ of the same ionic strength as the used buffer. The catalytic activity found was slightly higher than in pure water but not as high as in the buffer. We thus infer that ionic strength alone is not a sufficient indicator for a well-chosen 
reaction medium and that further savings in the media are not easily possible without sacrificing catalytic activity.

For further characterization of PtUGT1, we proceeded to work on Michaelis-Menten kinetics by measuring enzymemass specific initial rates for $10-150 \mu \mathrm{M}$ DCP. All experiments were done using $2.5 \mathrm{mM}$ UDPG. To be able to record initial rates via offline analytics at very low DCP concentrations, we had to adjust enzyme concentrations [E] down to $1-2 \mathrm{mg} / \mathrm{L}$. These experiments gave results that could not be rationalized, as no correlation was found between enzymatic activity and substrate concentration. Since the only parameter changed compared to the standard kinetic assay was [E], we systematically analyzed its influence on the specific enzymatic activity. The results are displayed in Figure 2 and

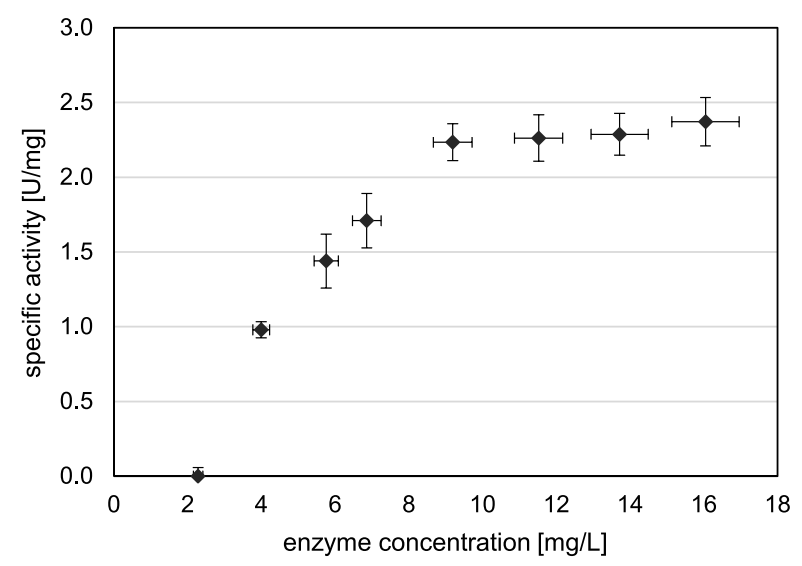

Figure 2. Mass specific activity of PtUGT1 at fixed substrate concentration, $[\mathrm{DCP}]=500 \mu \mathrm{M}$, and varied enzyme concentrations up to $16 \mathrm{mg} / \mathrm{L}$. Vertical error bars represent standard deviations of duplicated kinetic measurements, and horizontal error bars represent analytical triplicates of the protein assay. Experimental conditions: $500 \mu \mathrm{M}$ DCP, $2.5 \mathrm{mM}$ UDPG, $25 \mathrm{mM}$ HEPES, $50 \mathrm{mM} \mathrm{NaCl}$, pH 7.0, $2-16 \mathrm{mg} / \mathrm{L}$ enzyme at $40{ }^{\circ} \mathrm{C}$ and $1000 \mathrm{rpm}$.

show a plateau with a constant catalytic performance of PtUGT1 for enzyme concentrations $>8 \mathrm{mg} / \mathrm{L}$. For enzyme concentrations below this value, the activity drops drastically under the same conditions.

This finding forestalled the determination of $K_{M}$ for DCP in our respective system. To shed more light on this observation, we subjected the results to a deactivation analysis according to Selwyn. ${ }^{23}$ This analysis is based on the fact that for stable enzymatic activity, i.e., no enzyme deactivation, and constant reaction conditions, the reaction progress depends solely on enzyme concentration $[\mathrm{E}]$ and reaction time $t$. Thus, if the formation of substrate as a measure of reaction progress is plotted against $[\mathrm{E}] \times t$, all reactions without enzyme deactivation must coincide, even if performed at different enzyme concentrations. Only if the concentration of the active enzyme itself is a function of time will deviations become apparent. As can be seen in Figure 3, the observed product formation for reactions with more than $8 \mathrm{mg} / \mathrm{L}$ PtUGT1 can be described excellently by a joint regression. The others show a degressive trend which indicates time-dependent enzyme deactivation upon incubation of the enzyme in the reaction mixture containing all catalytic components.

Also, the different degrees of curvature show that the rate of enzyme deactivation indirectly depends on enzyme concentration. These results demonstrate that low $[\mathrm{E}]$ are to be

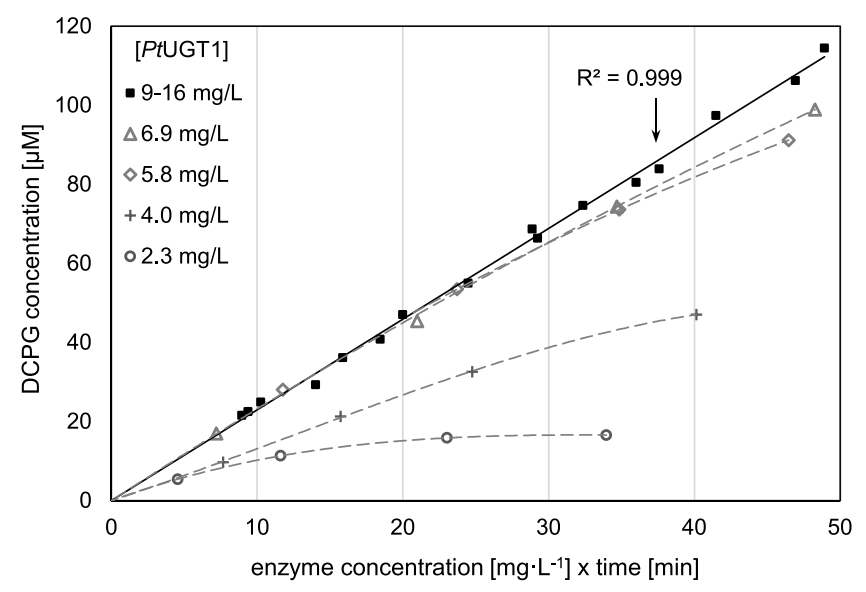

Figure 3. Enzyme deactivation analysis. Product formation at a fixed substrate concentration of $500 \mu \mathrm{M}$ and varying concentrations of free PtUGT1 in the reaction. Trendlines are given as a visual aid. Experimental conditions: $500 \mu \mathrm{M}$ DCP, $2.5 \mathrm{mM}$ UDPG, $25 \mathrm{mM}$ HEPES, $50 \mathrm{mM} \mathrm{NaCl}, \mathrm{pH} 7.0,2-16 \mathrm{mg} / \mathrm{L}$ enzyme at $40{ }^{\circ} \mathrm{C}$ and $1000 \mathrm{rpm}$.

avoided for stable enzymatic activity. The fact that Hsu and coworkers $^{13}$ were able to run kinetic experiments at enzyme concentrations as low as $1 \mathrm{mg} / \mathrm{L}$ can be attributed to the use of significant amounts of DTT in their reaction buffer. Both its reducing properties as well as its structural resemblance to well-known stabilizing polyols (e.g., glycerol, erythritol, and sorbitol) may explain this observation. Hence, regarding the operating window of PtUGT1, we conclude that the free enzyme suffers dilution-induced destabilization and that the use of additives-although beneficial at lab scale-can be avoided by adhering to threshold concentrations of the enzyme.

Regarding the long-term stability of PtUGT1, we report no activity losses for shock-frozen enzyme stocks that were stored at $-20{ }^{\circ} \mathrm{C}$ for several months. As Table 3 shows, the shelf-life

Table 3. Half-Life Times of Free PtUGT1 in HEPES Buffer $\left(\mathrm{pH}\right.$ 7.0) at Different Temperatures ${ }^{a}$

\begin{tabular}{clc} 
temperature & \multicolumn{1}{c}{ storage conditions } & half-life time $-t_{1 / 2}$ \\
$+4{ }^{\circ} \mathrm{C}$ & $\sim 6000 \mathrm{mg} / \mathrm{L} \mathrm{PtUGT1}$ & $122 \mathrm{~d}$ \\
$+40{ }^{\circ} \mathrm{C}$ & $67 \mathrm{mg} / \mathrm{L} \mathrm{PtUGT1} 1000 \mathrm{rpm}$ & $1.28 \mathrm{~h}$ \\
$+45{ }^{\circ} \mathrm{C}$ & $16.7 \mathrm{mg} / \mathrm{L}$ PtUGT1 & $0.60 \mathrm{~h}$
\end{tabular}

${ }^{a}$ Details on the decline of enzymatic activity are given in the Supporting Information, Figures S5-S7.

time was still considerable at a storage temperature of $+4{ }^{\circ} \mathrm{C}$. However, thermal stability under close-to-assay conditions proved to be significantly lower and only in the range of about $1 \mathrm{~h}$ (Table 3).

Knowing about the sensitivity of PtUGT1, we turned our attention to an immobilization strategy. For this, commercially available methacrylate carriers with well-defined product specifications and surface functionalities were screened. Both epoxy and amino resins with different pore diameters were considered for covalent immobilization. Different spacer lengths (C2 and C6) were also analyzed for amino carriers. The initial screening of all carriers was carried out at the lower end of the specified protein loading range, which is $50-100 \mathrm{mg}$ protein per gram of wet carrier. All results obtained are 
Table 4. Screening Results Obtained for the Immobilization of PtUGT1 on a Series of Different Lifetech Carriers ${ }^{a}$

\begin{tabular}{|c|c|c|c|c|c|}
\hline carrier & enzyme loading $[\mathrm{mg} / \mathrm{g}]$ & specific activity $^{b}\left[\mathrm{U} / \mathrm{g}_{\text {enzyme }}\right]$ & specific activity $\left[\mathrm{U} / \mathrm{g}_{\text {preparation }}\right]$ & $\eta_{\text {immo }}[\%]$ & $\eta_{\text {activity }}{ }^{c}[\%]$ \\
\hline ECR8204F & $38.3 \pm 0.1$ & $45.7 \pm 0.5$ & $1.75 \pm 0.02$ & $90.7 \pm 0.1$ & $1.62 \pm 0.10$ \\
\hline ECR8209F & $34.0 \pm 0.5$ & $97.6 \pm 0.1$ & $3.32 \pm 0.00$ & $80.8 \pm 1.1$ & $3.09 \pm 0.15$ \\
\hline ECR8215F & $37.7 \pm 0.1$ & $76.4 \pm 0.4$ & $2.88 \pm 0.02$ & $89.7 \pm 0.2$ & $2.69 \pm 0.15$ \\
\hline ECR8404F & $53.6 \pm 0.1$ & $20.1 \pm 1.1$ & $1.08 \pm 0.06$ & $94.8 \pm 0.2$ & $0.78 \pm 0.08$ \\
\hline ECR8409F & $53.3-54.1$ & $45.9 \pm 0.6$ & $2.45 \pm 0.03$ & $\geq 98.5$ & $1.85 \pm 0.11$ \\
\hline ECR8415F & $41.6-42.2$ & $70.5 \pm 1.0$ & $2.93 \pm 0.04$ & $\geq 98.5$ & $2.72 \pm 0.10$ \\
\hline ECR8304F & $54.4 \pm 0.2$ & $22.0 \pm 0.3$ & $1.20 \pm 0.02$ & $94.6 \pm 0.3$ & $0.85 \pm 0.05$ \\
\hline ECR8315F & $52.7 \pm 0.0$ & $60.1 \pm 0.4$ & $3.17 \pm 0.02$ & $98.1 \pm 0.1$ & $2.42 \pm 0.12$ \\
\hline
\end{tabular}

${ }^{a}$ All tested carriers share a common specified particle size of $150-300 \mu \mathrm{m}$. The mean pore diameters are $300-600 \AA$ ( $\left.8204 \mathrm{~F}, 8304 \mathrm{~F}, 8404 \mathrm{~F}\right), 600-$ $1200 \AA(8209 \mathrm{~F}, 8409 \mathrm{~F})$, and $1200-1800 \AA$ (8215F, 8315F, 8415F), respectively. The first three entries (82XX) cover epoxy-functionalized carriers. Amino-functionalized carries with $84 \mathrm{XX}$ have the longer C6 spacer, whereas 83XX have the shorter C2 spacer. Amino carriers required activation with glutaraldehyde prior to immobilization. Standard deviations are based on triplicate measurements of enzyme concentration and duplicates in progressive curve experiments. ${ }^{b}$ Per $[\mathrm{g}]$ enzyme immobilized. ${ }^{c}$ Per $[\mathrm{g}]$ enzyme offered during immobilization.
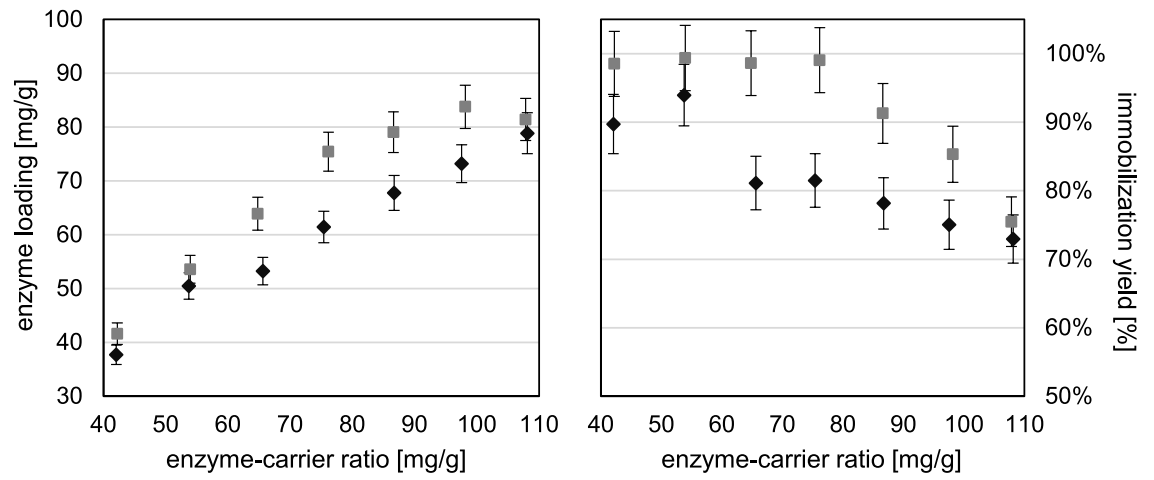

Figure 4. Enzyme loading and immobilization yields for PtUGT1 on epoxy-functionalized carrier ECR8215F ( $)$ and on amino-functionalized preactivated carrier ECR8415F (grey $\mathbf{0}$ ). Error bars represent standard errors of the enzyme assay.
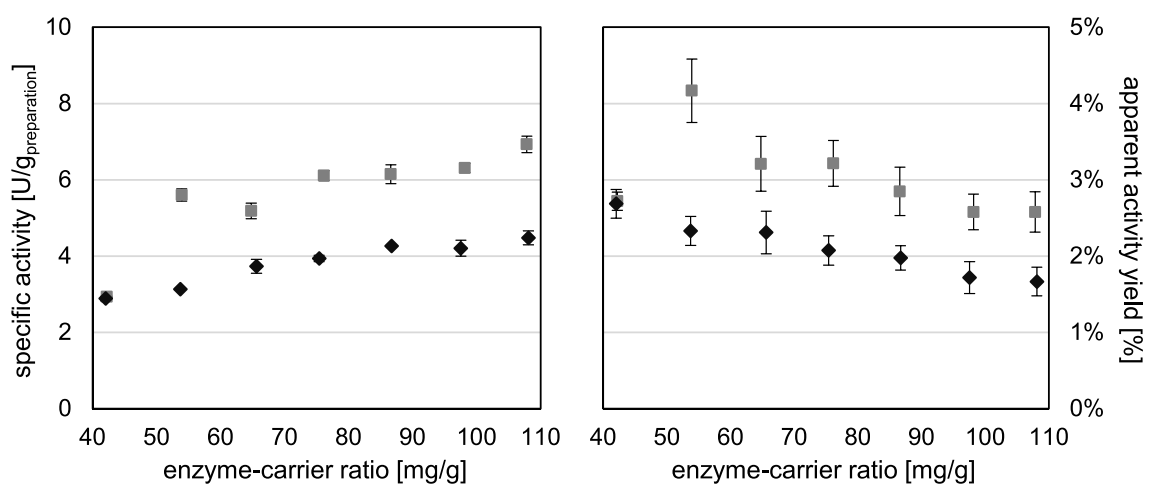

Figure 5. Specific activity of solid biocatalyst preparation and obtained apparent activity yields for PtUGT1 on epoxy-functionalized ECR8215F $(\downarrow)$ and amino-functionalized preactivated carrier ECR8415F (grey

\begin{abstract}
).
\end{abstract}
presented in Table 4. A detailed explanation how these parameters were derived is given in the Experimental Section.

In general, we found very high immobilization yields $\eta_{\text {immo }}$ for all carriers. Amino carriers gave better immobilization yields than epoxy carriers, and among the amino ones those with longer C6 spacers (84XXF) proved superior. In two cases, ECR8409F and ECR8415F, the remaining enzyme concentration in the immobilization supernatant was below the limit of detection (LOD) of the Pierce BCA protein assay used, which is why minimum immobilization yields of $98.5 \%$ are reported. Regarding catalytic activities, the better results were typically obtained for carriers with higher porosity. Preparations on carriers of the smallest pore size (300-600 $\AA$ ) gave highly linear reaction progress, which indicates mass transfer limitations. This can be rationalized by the inverse relation between tortuosity and pore size. No indications of such limitations were found for the other preparations (see Supporting Information, Figures S8-S15). However, in all cases the activity yields were in the daunting single-digit percentage range. For further investigations we opted for the most promising carriers of each type: ECR8415F with both best immobilization and activity yields among all amino carriers and ECR8215F with second best activity yield but best immobilization yield among the epoxy carriers. Next, we tested immobilizations at increased enzyme-carrier ratios of $50-100 \mathrm{mg} / \mathrm{g}$. Results of obtained enzyme loadings and immobilization yields are illustrated in Figure 4. The amino carrier outperformed the epoxy carrier in all cases and even granted near perfect immobilization yields for enzyme loadings up to $80 \mathrm{mg}_{\text {enzyme }} / \mathrm{g}_{\text {carrier }}$. 
The respective attained specific activities and activity yields are plotted in Figure 5. Here, the amino carrier immobilized enzyme preparations gave roughly $50 \%$ better performance than their respective epoxy carrier counterparts. The progressive curve of the best PtUGT1-ECR8415F preparation is provided in Figure 6. For all progress curves, two aspects are

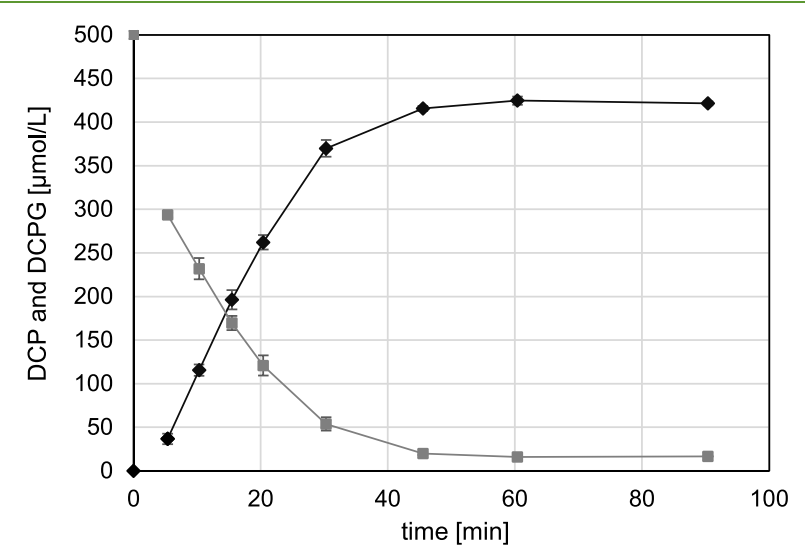

Figure 6. Progress curves of biocatalytic glycosylation using PtUGT1 immobilized on ECR8415F (54 $\left.\mathrm{mg}_{\text {enzyme }} / \mathrm{g}_{\text {carrier }}\right)$. Experimental duplicates were performed. Reaction progress was tracked for product formation (DCPG, ) and substrate depletion (DCP, grey $\mathbf{\square})$ in the supernatant. Lines connecting data points solely serve illustration purposes. Experimental conditions: $500 \mu \mathrm{M}$ DCP, $2.5 \mathrm{mM}$ UDPG, HEPES buffer ( $\mathrm{pH} 7.0,25 \mathrm{mM}$ HEPES, $50 \mathrm{mM} \mathrm{NaCl}$ ), $3.4 \mathrm{~g} / \mathrm{L}$ PtUGT1-ECR8415F corresponding to $184 \mathrm{mg} / \mathrm{L}$ enzyme at $40{ }^{\circ} \mathrm{C}$ and $1000 \mathrm{rpm}$.

to be highlighted: First, the product formation trace did not reach $500 \mu \mathrm{M}$ DCPG, which would correspond to complete substrate conversion. Second, the left-hand extrapolation of all product formation curves did not run through the origin of coordinates but always crosses the abscissa at $t>0 \mathrm{~min}$. We hypothesized that both these phenomena are caused by the retention of DCPG on the carrier. To verify this, we converted DCP to DCPG using free enzymes, controlled for complete conversion, and only then added ECR8415F carrier to the mixture. Any reduction of $[\mathrm{DCPG}]$ was then attributed to the carrier material. By doing so, we found that under our typical reaction conditions about $25 \mu \mathrm{mol}$ DCPG are retained per gram of wet carrier (see Supporting Information, Table S1).
With this parameter, it was possible to close the mass balances for the stationary state at the reaction's end.

However, without kinetic insights to the retention process, its influence on the shape of the product formation trace-and thereby on the observed initial rates-cannot be corrected for. The apparent shift in product formation to higher times indicates that DCPG retention already plays a strong role in the very beginning of the reaction. We conclude that this may affect the measured specific activities and results in an underestimation of the derived activity yields, which is why we decided to report them as "apparent activity yield" in Figure 5.

For the conditions used in Figure 6 we can thus report the complete conversion of substrate after a reaction time of $60 \mathrm{~min}$. To compare the heterogeneous biocatalyst with the free enzyme, its activity was analyzed in Milli-Q water and saline solution as well. However, the behavior of PtUGT1ECR8415F was very close to that of the free enzyme. Compared with its activity in HEPES buffer ( $\mathrm{pH}$ 7.0, $25 \mathrm{mM}$ HEPES, $50 \mathrm{mM} \mathrm{NaCl}$ ), it showed only $45 \%$ activity in Milli-Q and about $55 \%$ in saline solution ( $56 \mathrm{mM}$ ). It can be concluded that the enzyme activity does not become significantly more independent of changes in the reaction medium as a result of immobilization. Medium engineering aspects thus remain of great importance for proper process design.

Next, we evaluated the thermal stability of PtUGT1ECR8415F under close-to-assay conditions, the greatest weakness of the free enzyme (Table 3). The enzyme beads were suspended in HEPES reaction buffer $(\mathrm{pH} 7.0,25 \mathrm{mM}$ HEPES, $50 \mathrm{mM} \mathrm{NaCl}$ ) and exposed to $40{ }^{\circ} \mathrm{C}$ and $1000 \mathrm{rpm}$ for several days. At various points in time, aliquots of the beads were taken out and subjected to kinetic analysis. The found reaction rates were normalized to the catalyst amounts used and are shown in Figure 7. A half-life time of $60.7 \mathrm{~h}$ can be estimated from the decrease in catalytic activity over time (see Supporting Information, Figure S17).

With this parameter and the half-life time of the free enzyme, the stabilization factor achieved by immobilization can be calculated as follows:

$$
\text { Stabilization factor }=\frac{t_{1 / 2, \text { immo }}}{t_{1 / 2, \text { free }}}=\frac{60.7 \mathrm{~h}}{1.28 \mathrm{~h}}=47
$$

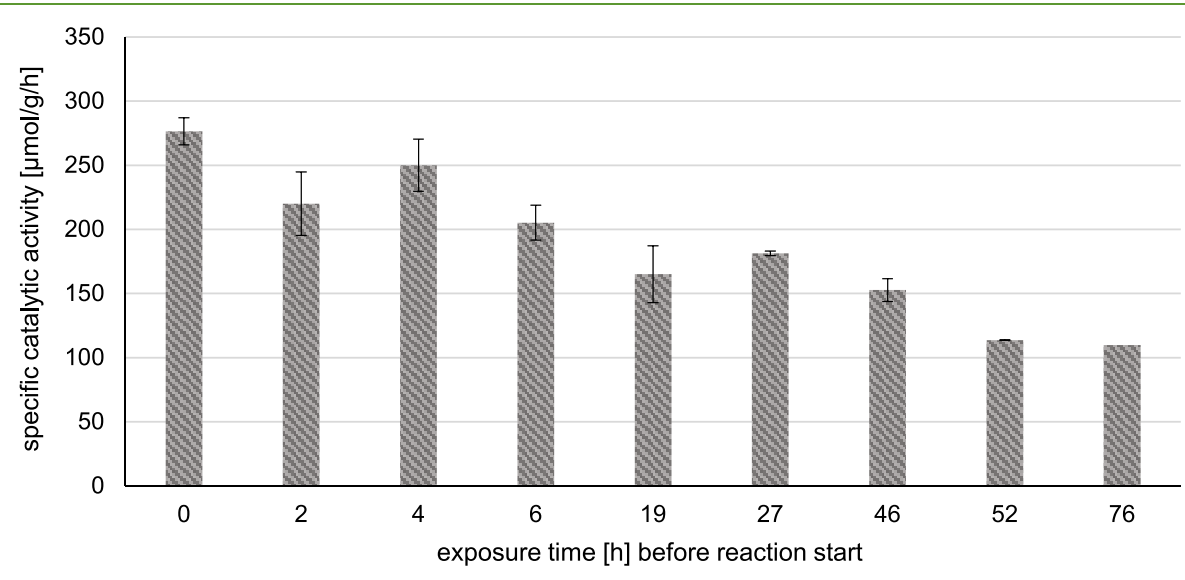

Figure 7. Residual specific productivities per gram of wet PtUGT1-ECR8415F after exposure to $+40{ }^{\circ} \mathrm{C}$ in HEPES buffer at $1000 \mathrm{rpm}$. With the exception of the last data point, all are based on experimental duplicates. Experimental conditions: $500 \mu \mathrm{M}$ DCP, $2.5 \mathrm{mM}$ UDPG, HEPES buffer ( $\mathrm{pH} 7.0,25 \mathrm{mM}$ HEPES, $50 \mathrm{mM} \mathrm{NaCl}$ ), 0.6-1.5 g/L PtUGT1-ECR8415F at $40{ }^{\circ} \mathrm{C}$ and $1000 \mathrm{rpm}$. 


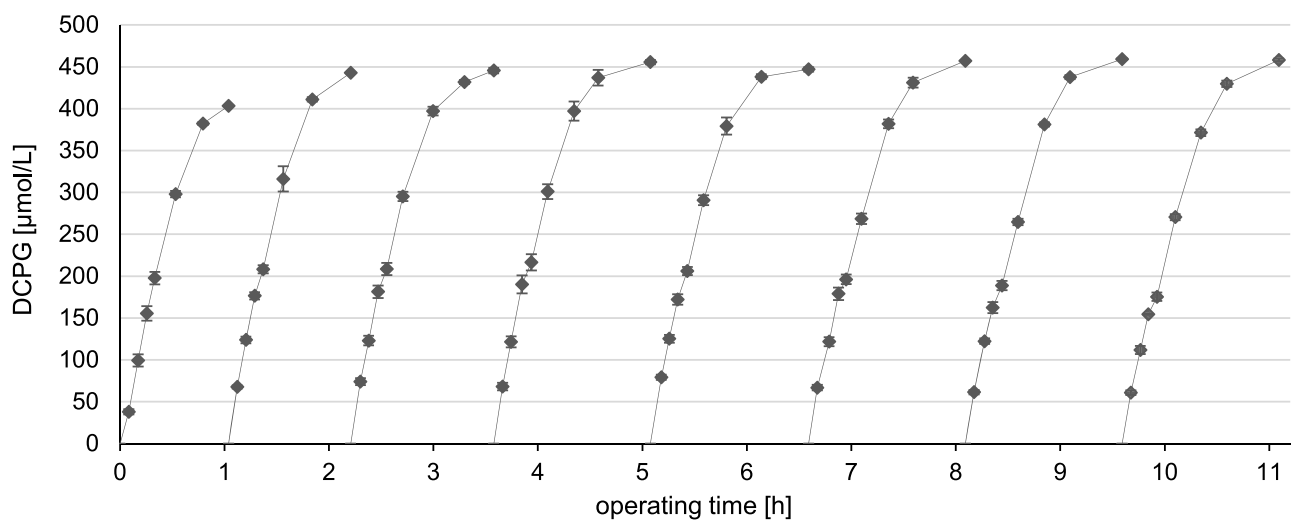

Figure 8. Formation of model product DCPG in repetitive batch experiments using our PtUGT1-ECR8415F preparation. After each batch, beads were rinsed twice with $400 \mu \mathrm{L}$ of buffer. Between batches 4 and 5 , the enzyme beads were stored overnight in HEPES buffer at $+4{ }^{\circ} \mathrm{C}$. Error bars represent standard deviations based on duplicate experiments. Lines connecting data points serve illustration purposes. Conditions: $500 \mu \mathrm{M} D C P$, $2.5 \mathrm{mM}$ UDPG, HEPES buffer (pH 7.0, $25 \mathrm{mM}$ HEPES, $50 \mathrm{mM} \mathrm{NaCl}$ ), $3.4 \mathrm{~g} / \mathrm{L}$ PtUGT1-ECR8415F, $1.5 \mathrm{~mL}$ reaction volume, $40{ }^{\circ} \mathrm{C}, 1000 \mathrm{rpm}$.

Notably, all kinetic experiments that are part of the data set displayed in Figure 7 eventually ran to $\geq 96 \%$ conversion, just at different rates. From these findings, it becomes apparent that the previously thermally and mechanically labile free enzyme strongly benefits from immobilization by improved stability, ease of handling, and reuse potential.

To answer the question whether the immobilization step is also justified by a gain in overall catalytic productivity, the following analysis was carried out: assuming an exponential decline in residual activity of either free PtUGT1 or PtUGT1ECR8415F, the overall catalytic productivities $\left(P_{j}\right)$ were compared using their respective initial activities $\left(a_{j}\right)$ and thermal stabilities $\left(k_{d, j}\right.$ deactivation constant, $t_{1 / 2}$ half-life time) as given:

$$
\begin{aligned}
& P_{j}=a_{j} \cdot \int_{0}^{+\infty} \mathrm{e}^{-k_{d, j} \cdot t} \mathrm{~d} t=\frac{a_{j}}{k_{d, j}} \\
& \text { relative productivity }=P_{\text {rel }}=\frac{P_{\text {immo }}}{P_{\text {free }}}=\frac{a_{\text {immo }}}{a_{\text {free }}} \cdot \frac{k_{d, \text { free }}}{k_{d, \text { immo }}} \\
& P_{\text {rel }}=\eta_{\mathrm{a}} \cdot \frac{k_{d, \text { free }}}{k_{d, \text { immo }}}=\eta_{\mathrm{a}} \cdot \frac{t_{1 / 2, \text { immo }}}{t_{1 / 2, \text { free }}}=0.0417 \cdot \frac{60.7}{1.28}=1.97
\end{aligned}
$$

Using this correlation and $\eta_{\mathrm{a}}$ as the apparent activity yield of our best PtUGT1-ECR8415F preparation (Figure 5), a doubling of the overall biocatalytic productivity (197\%) was estimated. However, since this conclusion is only based on the apparent activity yield, which is arguably underestimated due to product retention by the enzyme carrier, we regard this result as a conservative estimation.

Finally, we evaluated the reusability of our described enzyme beads in a repetitive batch experiment. This was carried out in two separate vessels to provide experimental duplicates. The results are illustrated in Figure 8. After each batch, the supernatant was carefully removed by a pipet, and the beads were rinsed twice with $400 \mu \mathrm{L}$ of HEPES buffer. It is noteworthy that the DCPG progress curves of batches $2-8$ all attained a higher DCPG concentration than the first batch. This indicates that a certain proportion of the typically carrierbound $25 \mu \mathrm{mol} / \mathrm{g}$ DCPG is retained and was not fully washed away. As a result, less DCPG is taken up by the carrier in the following batch. This leads to reproducible higher final DCPG concentrations, visibly steeper initial slopes, and reaction start points that are better aligned with the overall progress curve. In summary, the PtUGT1-ECR8415F catalyst was successfully (re)used in eight consecutive batches with average activity losses of roughly $2.5 \%$ per batch.

\section{CONCLUSION}

The catalytic activity of PtUGT1 was studied in lean aqueous media using the glycosylation of the model compound 3,4dichlorophenol (DCP). Both the cutback of salt and HEPES were associated with reduced activity, which indicates the need for ionic or concomitant organic substances to ensure efficient biocatalytic productivity. A self-stabilizing effect of free PtUGT1 was revealed since minimum enzyme concentrations were found to be necessary to sustain enzyme stability at low buffer concentrations.

Our immobilization study aimed to improve enzyme resilience and resulted in the biocatalyst preparation PtUGT1-ECR8415F, which displayed roughly 50-fold higher stability than the free enzyme. Despite seemingly weak activity yields, we conservatively estimated an associated doubling in productivity (197\%). The described heterogeneous biocatalyst is thus significantly better suited to be used for in vitro glycosylation. Also, due to the solid nature of the catalysts, catalyst-product separation is trivial. Since the dyeing step typically uses aqueous dye solutions, downstream processing of the biocatalytic reactor efflux is expected to be mainly limited to concentration or dilution and is thus most certainly more effortless than for in vivo synthesis.

The next step in the engineering of our proposed route is to decouple the consumption of costly UDPG from the formation of indican by introducing an efficient cosubstrate regeneration system. Successful examples thereof were recently published by Trobo-Maseda et al. ${ }^{24}$ and Liu et al. ${ }^{25}$ who coimmobilized a sucrose synthase with their glycosyltransferase. We understand that while this measure shifts the problem away from the expensive cosubstrate, it still requires hyperstoichiometric amounts of sucrose. However, the post-dyeing, sugarcontaining solution may be recycled as a carbon source for the cultivation of enzymes producing E. coli. Moreover, as our findings indicate, the presence of sugars in the reaction medium may even be beneficial for the activity of PtUGT1. 


\section{ASSOCIATED CONTENT}

\section{SI Supporting Information}

The Supporting Information is available free of charge at https://pubs.acs.org/doi/10.1021/acssuschemeng.1c01536.

HPLC analytics, UV spectra of 3,4-dichlorophenol and 3,4-dichlorophenol glucoside, shelf-life time and thermal stability of free PtUGT1, progress curves obtained for PtUGT1 immobilized on Lifetech ECR carriers, retention of DCP/DCPG by enzyme carrier ECR8415F, enzyme leaching test for PtUGT1ECR8415F, thermal stability of PtUGT1-ECR8415F, activity of $P t \mathrm{UGT} 1-\mathrm{ECR} 8415 \mathrm{~F}$ in different aqueous media, negative controls (PDF)

\section{AUTHOR INFORMATION}

\section{Corresponding Author}

Selin Kara - Biocatalysis and Bioprocessing Group,

Department of Biological and Chemical Engineering, Aarhus University, 8000 Aarhus C, Denmark; (1) orcid.org/0000-

0001-6754-2814; Email: selin.kara@bce.au.dk

\section{Authors}

Philipp Petermeier - Biocatalysis and Bioprocessing Group, Department of Biological and Chemical Engineering, Aarhus University, 8000 Aarhus C, Denmark

Cristina Fortuna - Biocatalysis and Bioprocessing Group, Department of Biological and Chemical Engineering, Aarhus University, 8000 Aarhus C, Denmark

Kathrine M. Hübschmann - Biocatalysis and Bioprocessing Group, Department of Biological and Chemical Engineering, Aarhus University, 8000 Aarhus C, Denmark

Gonzalo N. Bidart - The Novo Nordisk Foundation Center for Biosustainability, Technical University of Denmark, DK2800 Kongens Lyngby, Denmark

Thomas Tørring - Microbial Biosynthesis Group, Department of Biological and Chemical Engineering, Aarhus University, 8000 Aarhus C, Denmark

David Teze - The Novo Nordisk Foundation Center for Biosustainability, Technical University of Denmark, DK2800 Kongens Lyngby, Denmark

Ditte H. Welner - The Novo Nordisk Foundation Center for Biosustainability, Technical University of Denmark, DK2800 Kongens Lyngby, Denmark; ㅇo이.org/0000-00019297-4133

Complete contact information is available at:

https://pubs.acs.org/10.1021/acssuschemeng.1c01536

\section{Author Contributions}

S.K. developed the conception and design of this work. P.P. designed and conducted the experiments, performed data analysis and interpretation, and drafted the manuscript. C.F. and K.M.H. contributed to the kinetic characterization and to the experiments for enzyme immobilization. G.N.B. and D.T. contributed to ideation and scientific discussions, expressed and purified the enzyme, and conducted parts of the thermal stability experiments. T.T. contributed to the development of analytics. D.H.W. conceived the overall idea for the study, participated in discussions for the data interpretation and planning of experiments, provided funding, and commented on the manuscript. All authors have given approval to the final version of the manuscript.

\section{Funding}

This project has received funding from the European Union's Horizon 2020 research and innovation program under the Marie Skłodowska-Curie grant agreement no. 860414 and from The Novo Nordisk Foundation Grant number: NNF10CC1016517.

\section{Notes}

The authors declare no competing financial interest.

\section{ACKNOWLEDGMENTS}

We thank Dr. Alessandra Basso and Dr. Simona Serban from Purolite Ltd. (U.K.) for the kind provision of methacrylate immobilization carriers and for the fruitful discussions.

\section{ABBREVIATIONS}

DCP, 3,4-dichlorophenol; DCPG, 3,4-dichlorophenol glucoside; DTT, dithiothreitol; HEPES, 2-[4-(2-hydroxyethyl)-1piperazinyl]-ethanesulfonic acid; IPTG, isopropyl- $\beta$-D-thiogalactopyranosid; PtUGT1, glycosyltransferase 1 from Polygonum tinctorium; TFA, trifluoroacetic acid; UDPG, uridine $5^{\prime}$ diphosphate $\mathrm{P}^{\prime}-\alpha$-D-glucopyranoside; UDP, uridine $5^{\prime}$-diphosphate

\section{REFERENCES}

(1) Goffer, Z. Archaeological Chemistry, second ed.; John Wiley \& Sons, Inc.: Hoboken, NJ, 2007.

(2) Clark, R. J. H.; Cooksey, C. J.; Daniels, M. A. M.; Withnall, R. Indigo, woad, and Tyrian Purple: important vat dyes from antiquity to the present. Endeavour 1993, 17 (4), 191-199.

(3) Ahmed, H. E.; Tahoun, I. F.; Elkholy, I.; Shehata, A. B.; Ziddan, Y. Identification of natural dyes in rare Coptic textile using HPLCDAD and mass spectroscopy in museum of Faculty of Arts, Alexandria University, Egypt. Dyes Pigm. 2017, 145, 486-492.

(4) Bechtold, T.; Mussak, R. Handbook of Natural Colorants; John Wiley \& Sons Ltd.: Chichester, West Sussex, United Kingdom, 2009; p 412 .

(5) Balfour-Paul, J. Indigo: Egyptian Mummies to Blue Jeans; Firefly Books Ltd.: Richmond Hill, Ontario, 2011; p 264.

(6) Abdel-Kareem, O. History of Dyes Used in Different Historical Periods of Egypt. Res. J. Text. Apparel 2012, 16 (4), 79-92.

(7) Alt, K. W.; Burger, J.; Simons, A.; Schön, W.; Grupe, G.; Hummel, S.; Grosskopf, B.; Vach, W.; Téllez, C. B.; Fischer, C.-H.; Möller-Wiering, S.; Shrestha, S. S.; Pichler, S. L.; Driesch, A. v. d. Climbing into the past-first Himalayan mummies discovered in Nepal. J. Archaeol. Sci. 2003, 30 (11), 1529-1535.

(8) Van Olphen, H. Maya Blue: A Clay-Organic Pigment? Science 1966, 154 (3749), 645-646.

(9) Wolf, L. K. Blue Jeans. Chem. Eng. News 2011, 89 (43), 44 [accessed February 20, 2021]. ISSN: 0009-2347.

(10) Roshan, P. Denim, 1st ed.; Woodhead Publishing: Sawston, Cambridge, UK, 2015.

(11) Schimper, C. B.; Ibanescu, C.; Bechtold, T. Surface activation of dyed fabric for cellulase treatment. Biotechnol. J. 2011, 6 (10), $1280-1285$.

(12) Shahbandeh, M. Global Denim Market - Statistics \& Facts; Statista, 2020

(13) Hsu, T. M.; Welner, D. H.; Russ, Z. N.; Cervantes, B.; Prathuri, R. L.; Adams, P. D.; Dueber, J. E. Employing a biochemical protecting group for a sustainable indigo dyeing strategy. Nat. Chem. Biol. 2018, 14 (3), 256-261.

(14) Berry, A.; Dodge, T. C.; Pepsin, M.; Weyler, W. Application of metabolic engineering to improve both the production and use of biotechn indigo. J. Ind. Microbiol. Biotechnol. 2002, 28, 127-133.

(15) Fabara, A. N.; Fraaije, M. W. Production of indigo through the use of a dual-function substrate and a bifunctional fusion enzyme. Enzyme Microb. Technol. 2020, 142, 109692. 
(16) Fabara, A. N.; Fraaije, M. W. An overview of microbial indigoforming enzymes. Appl. Microbiol. Biotechnol. 2020, 104 (3), 925933.

(17) Song, J.; Imanaka, H.; Imamura, K.; Kajitani, K.; Nakanishi, K. Development of a highly efficient indigo dyeing method using indican with an immobilized beta-glucosidase from Aspergillus niger. J. Biosci. Bioeng. 2010, 110 (3), 281-7.

(18) Teze, D.; Coines, J.; Fredslund, F.; Dubey, K. D.; Bidart, G. N.; Adams, P. D.; Dueber, J. E.; Svensson, B.; Rovira, C.; Welner, D. H. $\mathrm{O}-/ \mathrm{N}-/ \mathrm{S}-\mathrm{Specificity}$ in Glycosyltransferase Catalysis: From Mechanistic Understanding to Engineering. ACS Catal. 2021, 11 (3), 18101815.

(19) Shiu, W.-Y.; Ma, K.-C.; Varhaníčková, D.; Mackay, D. Chlorophenols and Alkylphenols: A Review and Correlation of Environmentally Relevant Properties and Fate in an Evaluative Environment. Chemosphere 1994, 29 (6), 1155-1224.

(20) Robinson, R. A. Ionization Constants of the Six Dichloroanilines and the Six Dichlorophenols in Aqueous Solution at $25^{\circ} \mathrm{C}$. J. Res. Natl. Bur. Stand., Sect. A 1964, 68A (2), 159-164.

(21) Beltrame, P.; Beltrame, P. L.; Carniti, P. Inhibition action of chloro- and nitro-phenols on biodegradation of phenols: A structuretoxicity relationship. Chemosphere 1984, 13 (1), 3-9.

(22) ACD/Labs, version 11.02; Advanced Chemistry Development, Inc.: Toronto, ON, Canada, 2021; www.acdlabs.com.

(23) Selwyn, M. J. A simple test for inactivation of an enzyme during assay. Biochim. Biophys. Acta, Enzymol. Biol. Oxid. 1965, 105 (1), 193-195.

(24) Trobo-Maseda, L.; Orrego, A. H.; Guisan, J. M.; Rocha-Martin, J. Coimmobilization and colocalization of a glycosyltransferase and a sucrose synthase greatly improves the recycling of UDP-glucose: Glycosylation of resveratrol 3-O-beta-D-glucoside. Int. J. Biol. Macromol. 2020, 157, 510-521.

(25) Liu, H.; Tegl, G.; Nidetzky, B. Glycosyltransferase CoImmobilization for Natural Product Glycosylation: Cascade Biosynthesis of the C-Glucoside Nothofagin with Efficient Reuse of Enzymes. Adv. Synth. Catal. 2021, 363, 2157-2169. 